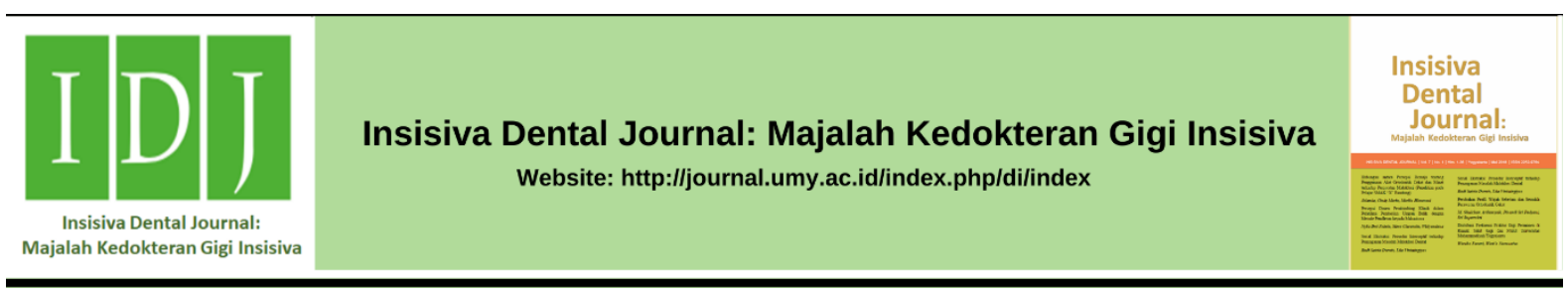

Research Article

\title{
Efektivitas Topikal Aplikasi Dadih terhadap Inflamasi Gingiva
}

\author{
The Effectiveness of Topical Application of Curd on Gingival Inflamation
}

\author{
Vanny Fergiana Mulyadi, Nurul Syifa Putri Wesha, Satria Yandi, Valendriyani Ningrum* \\ Fakultas Kedokteran Gigi Universitas Baiturrahmah, Jl. Raya By Pass KM 14, Kuranji, Padang, Indonesia.
}

Received date: August 28 ${ }^{\text {th }}, 2019$; reviewed date: October $16^{\text {th }}, 2019$; revised date: March $4^{\text {th }}, 2020$; accepted date: March $11^{\text {st }}, 2020$ DOI : $10.18196 /$ di.9110

\begin{abstract}
Abstrak
Dadih adalah produk fermentasi susu kerbau dengan menggunakan bambu dan merupakan makanan khas Sumatera Barat. Dadih mengandung Lactobacillus casei yang merupakan probiotik yang memiliki kemampuan untuk menghambat perlekatan bakteri patogen, merusak reseptor toksin dan menghancurkan toksin. Kandungan antioksidan dan probiotik tersebut mampu mengatasi peradangan. Penelitian ini bertujuan untuk mengetahui efektivitas topikal aplikasi dadih pada inflamasi gingiva. Penelitian ini menggunakan metode eksperimental dengan menggunakan hewan uji tikus wistar. Tiga puluh tiga tikus galur Wistar yang mengalami inflamasi gingiva setelah diinduksi secara traumatik dibagi dalam tiga kelompok. Kelompok 1 diberi perlakuan aplikasi dadih topikal, kelompok 2 kontrol positif dengan aplikasi Kenalog dan kelompok 3 kontrol negatif dengan menggunakan plasebo. Perubahan klinis dievaluasi dengan indeks gingiva Loe dan Silness dengan mengamati penyembuhan inflamasi gingiva selama sebelas hari. Hasil penelitian menunjukkan jumlah gingiva hewan uji yang sembuh pada kelompok topikal aplikasi dadih (8 ekor), kontrol positif (8 ekor) dan kontrol negatif (3 ekor). Hasil uji Kruskal Wallis (p 0,04) secara signifikan menunjukkan adanya perbedaan efektivitas dari ketiga kelompok tersebut dan analisis post hoc dengan uji Mann Whitney (p 1,00) menunjukkan efektivitas yang sama pada kelompok topikal aplikasi dadih dan kontrol positif. Dapat disimpulkan bahwa topikal aplikasi dadih memiliki efek signifikan dalam penyembuhan inflamasi gingiva yang setara dengan kontrol positif.
\end{abstract}

Kata Kunci: Dadih; Inflamasi Gingiva; Probiotik; Herbal

\begin{abstract}
Curd is a product of buffalo milk fermentation using bamboo and is a traditional product of West Sumatra. It contains Lactobacillus casei, which is a probiotic that could inhibit the attachment of pathogenic bacteria, damage the toxin receptors, and destroy the toxin. The antioxidants and probiotic contents can overcome inflammation. This study aims to determine the effectiveness of the topical application of curd on gingival inflammation. This study is an experimental study using a Wistar rat test. Thirty-three Wistar strain rats that experienced gingival inflammation upon being traumatically induced were divided into three groups. Group 1 was treated with topical application of curd, while group 2 was positive control with Kenalog application, and group 3 was negative control using a placebo. Clinical changes were evaluated with the Silness and the Loe gingival index by observing the healing process of gingival inflammation for eleven days. The result showed that the number of the recovered rats of gingival test in the group of topical application of curd was 8 rats, while positive control group showed 8 recovered rats, and negative control group showed 3 rats. The Kruskal Wallis test results ( $p$ 0.04) significantly showed the differences in the effectiveness among the three groups while the post hoc analysis with the Mann Whitney test (p 1.00) showed the same effectiveness between the group of topical application of curd and the positive control group. It can be concluded that the topical application of curd has a significant effect in the healing process of gingival inflammation, which is equivalent to the positive control.
\end{abstract}

Keywords: Curd, Gingival Inflammation, Probiotics, Herb

* Corresponding author, e-mail: valend888@gmail.com 


\section{PENDAHULUAN}

Inflamasi gingiva adalah peradangan pada gingiva yang disebabkan mikroorganisme yang membentuk suatu koloni pada permukaan gigi. ${ }^{1}$ Tanda-tanda klinis perubahan warna lebih merah dari normal, gusi bengkak dan berdarah pada tekanan ringan. ${ }^{2,3}$ Etiologi inflamasi gingiva yang merupakan bagian dari penyakit periodontal adalah adalah bakteri. Interaksi ekologis antara inang dan mikroba menentukan tingkat keparahan penyakit. Tidak seperti banyak penyakit menular, penyakit periodontal tampaknya merupakan infeksi yang dimediasi oleh pertumbuhan berlebih dari organisme komensal, bukan oleh perolehan patogen eksogen. ${ }^{4}$

Prevalensi inflamasi pada gingiva sebanyak 93.9\%.5 Perawatan inflamasi gingiva yaitu menghilangkan plak dan kalkulus dengan scalling, memperbaiki faktor retensi plak dan perawatan medikasi dengan obat antiinflamasi dan antibiotik. Obat-obatan anti inflamasi memiliki efek samping seperti reaksi alergi, perdarahan saluran cerna, hipertensi, gastritis, gagal ginjal, miopati, osteoporosis dan efek samping pada organ kardiovaskular. ${ }^{6,7}$ Pengobatan dari bahan alami yang potensial masih sangat berpeluang untuk dikembangkan untuk meminimalisir efek samping tersebut, salah satu bahan tersebut adalah dadih.

Dadih merupakan produk fermentasi susu kerbau yang difermentasikan di dalam tabung bambu dan berasal dari Sumatera Barat. Proses fermentasi dilakukan oleh bakteri asam laktat yang secara alami ada di dalam susu kerbau. ${ }^{8}$ Dadih mengandung 16 jenis asam amino dari 20 asam amino yang ada di alam. Bakteri asam laktat yang telah berhasil diisolasi dalam dadih di identifikasi sebanyak 36 strain. ${ }^{9}$ Kandungan bakteri asam laktat di dalam dadih mempunyai kemampuan dalam memproduksi substrat antimikroba yang bersifat antagonistik terhadap bakteri patogen kususnya bakteriosin. Bakteri asam laktat pada dadih yang paling banyak dijumpai adalah Lactobacillus casei. Selain itu, dadih berguna sebagai antioksidan dan antibakteri. ${ }^{10,11}$

Probiotik

merupakan

mikroorganisme hidup yang dapat meningkatkan kesehatan manusia dengan menghasilkan berbagai nutrisi untuk inangnya, mencegah infeksi yang dan memodulasi respons imunologis. ${ }^{12}$ Probiotik mendatangkan banyak manfaat untuk kesehatan rongga mulut, secara langsung berinteraksi dengan plak gigi dan dapat mencegah terjadinya pembentukan plak dengan cara melawan dan terlibat dengan bakteri yang melekat secara langsung. Probiotik secara tidak langsung dapat meningkatkan sistem imun. ${ }^{13}$ Sehingga efektivitas dadih terhadap penyembuhan inflamasi gingiva menarik untuk diketahui.

\section{MATERIAL DAN METODE}

Penelitian ini menggunakan metode eksperimental dengan menggunakan hewan uji tikus wistar. Sebelum dilakukan penelitian terlebih dahulu penelitian ini sudah mendapatkan keterangan lulus kajian etik. Sampel yang digunaan adalah tikus wistar sebanyak 33 ekor dan dibagi kedalam 3 kelompok yaitu 11 ekor untuk kelompok perlakuan dadih, 11 ekor untuk kelompok kontrol negatif dan 11 ekor untuk kelompok kontrol positif. Tikus yang digunakan dengan kriteria sehat (gerak aktif, rambut tidak kusam, rontok, atau botak), memiliki berat badan $180-200$ gram, berusia sekitar 2-3 bulan.

Pembuatan pasta dadih dengan cara memanaskan susu kerbau dengan suhu $70^{\circ} \mathrm{C}$ selama 20-30 menit. Dinginkan susu kerbau dalam suhu $30^{\circ} \mathrm{C}$. Bersihkan bagian dalam tabung bambu terlebih dahulu, kemudian masukkan susu kerbau yang telah didinginkan kedalam tabung bambu. Tutup dengan daun pisang dan ikat dengan karet gelang. Simpan pada suhu ruang 2 x 24 jam. Induksi inflamasi gingiva dilakukan secara traumatik yang dimulai dengan melakukan tindakan intramuskular pada otot paha 
belakang dengan dosis $0,2 \mathrm{ml} / 200$ gram berat BB. Selanjutnya, semua tikus mendapatkan pengolesan $\mathrm{H}_{2} \mathrm{O}_{2} 35 \%$ pada gingiva 2 kali sehari selama 3 hari berturutturut hingga terjadi inflamasi gingiva.

Tahap penelitian dimulai dengan membagi tikus wistar kedalam 3 kelompok yaitu kelompok yang diberi dadih sebagai kelompok perlakuan, kenalog in orabase sebagai kelompok kontrol positif dan plasebo sebagai kelompok kontrol negatif. Tahap penelitian selanjutnya dilakukan dengan mengoleskan dadih, kenalog dan plasebo dengan cotton bud 1 kali tiap 5 menit sebanyak 3 kali sehari pada masingmasing kelompok tikus wistar. Pengamatan jumlah tikus yang sembuh diamati hingga hari ke-11. Penyembuhan inflamasi gingiva dapat dilihat secara klinis dengan mengamati perubahan gingiva dari inflamasi menjadi normal yaitu perubahan warna yang tadinya merah (rubor) menjadi pink coral dan berkurangnya bengkak. Perubahan klinis dievaluasi dengan indeks gingiva Loe dan Silness (1963). ${ }^{14}$

\section{HASIL}

Jumlah tikus wistar yang sembuh pada hari ke-11 pada kelompok perlakuan dadih adalah sebanyak 8 ekor, kelompok kontrol positif sebanyak 8 ekor dan kelompok kontrol negatif tikus sembuh sebanyak 3 ekor (grafik 1).

JUMLAH TIKUS YANG SEMBUH

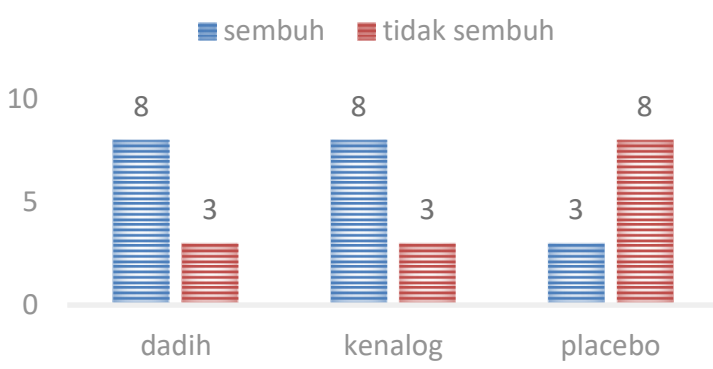

Grafik 1. Jumlah tikus wistar yang sembuh Uji normalitas menunjukkan bahwa data tidak berdistribusi normal, sehingga selanjutnya dilakukan uji Kruskal wallis. Hasil uji Kruskal wallis menunjukkan hasil $\mathrm{p}=0,04(\mathrm{p}<0,05)$ yang artinya terdapat perbedaan efektivitas penyembuhan inflamasi gingiva pada ketiga kelompok perlakuan tersebut. Analisis statistik selanjutnya dilanjutkan dengan uji MannWhitney untuk mengetahui perbedaan antar dua kelompok. Hasil analisis statistik memperlihatkan nilai $\mathrm{p}=1,00$ yang bermakna tidak ada perbedaan pada kelompok topikal aplikasi dadih dan Kenalog. Berdasarkan hasil analisis tersebut maka dadih dan kenalog secara statistik memiliki efektivitas yang sama.

\section{PEMBAHASAN}

Efektivitas dadih sama dengan kontrol positif menunjukkan bahwa dadih berpeluang dikembangkan menjadi salah satu bahan terapi alternatif dalam penyembuhan inflamasi gingiva. Hal tersebut dikarenakan peran dari probiotik yang terkandung pada dadih dapat berperan sebagai antibiotik, anti-inflamasi dan mempercepat penyembuhan luka. ${ }^{15,16}$

Pengobatan penyakit periodontal dengan antibiotik konvensional belum efektif, sehingga diperlukan pengobatan alternatif yang mengandung peptida dan protein antimikroba, yang dapat bersifat bakterisidal dan memblokir efek inflamasi dari toksin bakteri. ${ }^{17}$ Sementara itu, probiotik yang terkandung pada dadih mampu memodulasi sistem kekebalan inang, menghambat aktivitas bakteri patogen, atau bertindak terhadap produk mikroba. ${ }^{18,19}$ Bakteriosin, yang diproduksi oleh probiotik merupakan peptida antimikroba yang menunjukkan potensi signifikan terhadap bakteri lain, stabil dan dapat memiliki aktivitas pada spektrum sempit atau luas. $^{20}$ Selain memiliki mekanisme melawan patogen, probiotik memiliki kemampuan untuk menjaga kelangsungan hidup pada organ, meningkatkan penyerapan dan kinerja nutrisi. $^{21,22}$

Hasil penelitian ini juga didukung oleh sebuah studi yang menyatakan bahwa pada probiotik memiliki mekanisme antiinflamasi melalui penekanan signal sitokin sehingga mampu melawan infeksi. ${ }^{23}$ Pengurangan sitokin proinflamasi dalam 
menjadi bukti pendekatan probiotik memerangi peradangan di rongga mulut. ${ }^{24}$ Produk probiotik yang telah dikembangkan dalam bentuk susu atau obat kumur mampu mengurangi efek peradangan gingiva yang diinduksi plak..$^{25,26}$

Kemampuan dadih dalam mempercepat penyembuhan luka pada studi ini didukung oleh penelitian Baquerizo dkk. (2014), ${ }^{27}$ bahwa salah satu sifat probiotik mampu membantu penyembuhan luka. Studi Khodaii dkk. (2019), ${ }^{28}$ menjelaskan bahwa terjadi penurunan aktivitas inflamasi, peningkatan jumlah kolagen secara signifikan, dan kecepatan epitelisasi pada kelompok hewan uji yang diberi perlakuan berupa salep probiotik.

\section{KESIMPULAN}

Pemberian topikal aplikasi dadih dapat dikembangkan menjadi bahan terapi alami dalam penyembuhan inflamasi gingiva. Penelitian ini masih perlu dikembangkan melalui pendekatan ilmiah lebih lanjut.

\section{DAFTAR PUSTAKA}

1. Cobb, C.M. Microbes, inflammation, scaling and root planing, and the periodontal condition. J. Dent. Hyg. 2008; 82(Suppl 3): 4-9.

2. Rajendran A, Sivapathasundharam B. Shafer's Textbook of Oral Pathology. Elsevier Health Sciences; 2014.

3. Carvajal P, Gómez M, Gomes S, Costa R, Toledo A, Solanes F, et al. Prevalence, severity, and risk indicators of gingival inflammation in a multicenter study on South American adults: a cross sectional study. J Appl Oral Sci. 2016; 24(5): 524-34.

4. Cekici A, Kantarci A, Hasturk H, Van Dyke TE. Inflammatory and immune pathways in the pathogenesis of periodontal disease. Periodontol 2000. 2014; 64(1): 57-80.

5. Li Y, Lee S, Hujoel P, Su M, Zhang W, Kim J, et al. Prevalence and severity of gingivitis in American adults. Am J Dent. 2010; 23(1): 9-13.

6. Wongrakpanich S, Wongrakpanich A, Melhado K, Rangaswami J. A Comprehensive Review of NonSteroidal Anti-Inflammatory Drug Use in The Elderly. Aging Dis. 2018; 9(1): 143-50.

7. Roshi D, Toçi E, Burazeri G, SchröderBäck P, Malaj L, Brand H. Users' Knowledge About Adverse Effects of Non-steroidal Anti-inflammatory Drugs in Tirana, Albania. Mater Sociomed. 2017; 29(2): 138-42.

8. Rizqiati, H., Sumantri, C., Noor, R. R., Damayanthi, E., \& Rianti, E. I. Isolation and identification of indigenous lactic acid bacteria from North Sumatra river buffalo milk. Jurnal Ilmu Ternak dan Veteriner, 2015; 20(2): 87-94.

9. Sunarlim, R. Potensi lactobacillus sp. asal dari dadih sebagai starter pada pembuatan susu fermentasi khas Indonesia. Buletin Teknologi Pasca Panen, 2016; 5(1): 69-76.

10. Kodariah, R., Armal, H. L., Wibowo, H., \& Yasmon, A. The effect of dadih in $\mathrm{BALB} / \mathrm{c}$ mice on pro-inflammatory and anti-inflammatory cytokine productions. Journal of the Medical Sciences (Berkala ilmu Kedokteran), 2019; 51(4): 292-300.

11. Hasim, M. A., \& Andrianto, N. Fatimah and Faridah DN. Antioxidant Production of Lactic Acid Bacteria Isolated from Indonesian Traditional Fermented Buffalo Milk (Dadih). IOSR Journal of Pharmacy and Biological Sciences, 2017; 12(5): 76-82.

12. Markowiak P, Śliżewska K. Effects of Probiotics, Prebiotics, and Synbiotics on Human Health. Nutrients. 2017; 9(9): 1021.

13. Haukioja A. Probiotics and Oral Health. Eur J Dent. 2010; 04(03): 348-355.

14. Löe H, Silness J. Periodontal Disease in Pregnancy I. Prevalence and Severity. Acta Odontol Scand. 1963; 21(6): 53351. 
15. Rodrigues KL, Caputo LRG, Carvalho JCT, Evangelista J, Schneedorf JM. Antimicrobial and healing activity of kefir and kefiran extract. Int $J$ Antimicrob Agents . 2005; 25(5): 404-8.

16. Quigley EMM. Therapies aimed at the gut microbiota and inflammation: antibiotics, prebiotics, probiotics, synbiotics, anti-inflammatory therapies. Gastroenterol Clin N.. 2011; 40(1): 207-222.

17. Gorr S-U, Abdlhosseini M. Antimicrobial peptides and periodontal disease. J Clin Periodontol . 2011; 38(s11): 126-141.

18. Oelschlaeger TA. Mechanisms of probiotic actions - A review. Int. J. Med. Microbiol. 2010; 300(1): 57-62.

19. Jones SE, Versalovic J. Probiotic Lactobacillus reuteribiofilms produce antimicrobial and anti-inflammatory factors. BMC Microbiology. 2009; 9(1): 35.

20. Cotter PD, Ross RP, Hill C. Bacteriocins - a viable alternative to antibiotics? Nat. Rev. Microbiol. 2013; 11(2): 95-105.

21. McFarland LV. Evidence-based review of probiotics for antibiotic-associated diarrhea and Clostridium difficile infections. Anaerobe. 2009; 15(6): 27480.

22. Edens, F. W. An alternative for antibiotic se in poultry: probiotics. Braz. J. Poult. Sci. 2003; 5(2): 75-97.
23. Lee JS, Paek NS, Kwon OS, Hahm KB. Anti-inflammatory actions of probiotics through activating suppressor of cytokine signaling (SOCS) expression and signaling in Helicobacter pylori infection: A novel mechanism. $J$ Gastroenterol Hepatol. 2010; 25(1): 194-202.

24. Twetman S, Derawi B, Keller M, Ekstrand K, Yucel-Lindberg T, Stecksén-Blicks C. Short-term effect of chewing gums containing probiotic Lactobacillus reuteri on the levels of inflammatory mediators in gingival crevicular fluid. Acta Odontol Scand. 2009; 67(1): 19-24.

25. Slawik S, Staufenbiel I, Schilke R, Nicksch S, Weinspach K, Stiesch M, et al. Probiotics affect the clinical inflammatory parameters of experimental gingivitis in humans. Eur J Clin Nutr. 2011; 65(7): 857-863.

26. Noordin, K., \& Kamin, S. The Effect of probiotic mouthrinse on plaque and gingival inflammation. Ann Dent UM. 2007; 14(1): 19-25.

27. Baquerizo Nole KL, Yim E, Keri JE. Probiotics and prebiotics in dermatology. J Am Acad Dermatol. 2014; 71(4): 814-821.

28. Khodaii, Z., Afrasiabi, S., Hashemi, S. A., Ardeshirylajimi, A., \& Natanzi, M. M. Accelerated wound healing process in rat by probiotic Lactobacillus reuteri derived ointment. J Basic Clin Physiol Pharmacol. 2019; 30(3). 